\title{
Pengaruh Penambahan Tepung Tulang Sotong (Cuttelfish bone) dalam Ransum terhadap Konsumsi Pakan, Pertambahan Bobot Badan, dan Karkas Ayam Pedaging
}

\author{
Damary Widharto dan W. Marsudi
}

Akademi Peternakan Karanganyar

E-mail : damaryw@ymail.com

\begin{abstract}
Abstrak
Penelitian ini dilakukan dengan bertujuan untuk mengetahui pengaruh pemberian tepung tulang sotong dalam ransum terhadap konsumsi pakan, pertambahan bobot badan harian (Average Daily Gain), dan berat karkas. Sebanyak 60 ekor ayam broiler umur sehari dibagi menjadi 4 perlakuan yaitu perlakuan kontrol (T-0), kelompok ayam yang diberi pakan basal konsentrat tanpa penambahan tepung tulang; Kelompok perlakuan 1 (T-1), kelompok ayam yang diberi pakan basal konsentrat dengan penambahan tepung tulang sebanyak $1 \%$ dari pakan; Kelompok perlakuan 2 (T-2), kelompok ayam yang diberi pakan basal konsentrat dengan penambahan tepung tulang sebanyak 1,5\% dari pakan, dan Kelompok perlakuan 3 (T-3), kelompok ayam yang diberi pakan basal konsentrat dengan penambahan tepung tulang sebanyak $2 \%$ dari pakan.Variabel yang diamati dalam penelitian ini adalah konsumsi pakan, pertambahan bobot badan harian, dan berat karkas ayam pedaging. Data yang diperoleh dianalisis dengan Anova dan dilanjutkan dengan uji lanjut Duncant Multiple Range Test. Hasil penelitian menunjukkan bahwa konsumsi pakan untuk masing-masing perlakuan sebanyak 54,59 (T-0), 55,71 (T-1), 58,77 (T-2), 58,55 g/ekor/hari (T3), pertambahan bobot badan harian sebesar 38,8 (T-0), 41,5 (T-1), 40,6 (T-2) and 38,7 g/ekor/hari (T-3), dan berat karkas sebesar 531,33 (T-0), 750,67 (T-1), 761,67 (T-2), 770,67 g/ekor/hari (T-3). Kesimpulan dari penelitian adalah penambahan tepung tulang sotong dalam ransum belum dapat meningkatkan konsumsi pakan, dan pertambahan bobot badan harian, tetapi dapat meningkatkan bobot karkas ayam pedaging.
\end{abstract}

Kata kunci : Broiler, Karkas, dan Tepung Tulang Sotong

\begin{abstract}
This research was conducted to to know influence of cuttlefish bone flour in ransum to feed consumption, average daily gain, and carcasse weight. The research use 60 day old chick of broilers which were devided into 4 treatments, that is 1) control treatment $(T-0)$, broiler were given concentrate feed without addition of cuttlefish bone flour, 2) $T-1$, broiler were given concentrate feed with addition of cuttlefish bone flour as much as $1 \%$, 3) $T-2$, broiler were given concentrate feed with addition of cuttlefish bone flour as much as $1.5 \%$, and 4) $T-3$, broiler were given concentrate feed with addition of cuttlefish bone flour as much as $2 \%$. The variables observed feed consumption, average daily gain, and carcasse weight. The result showed that feed consumption is $54.59(T-0), 55.71(T-1), 58.77(T-2), 58.55 \mathrm{~g} / \mathrm{head} /$ day $(T-3)$, average daily gain is $38.8(T-$ 0), 41.5 ( $(T-1), 40.6$ ( $T-2)$ and 38.7 (g/head/day $T-3)$, and carcasse weight 531.33 (T-0), 750.67 ( $T-1), 761.67$ (T-2), $770.67 \mathrm{~g} / \mathrm{head} /$ day $(T-3)$. Research conclusion is addition of cuttlefish bone flour in ration not yet to improve feed consumption, and average daily gain, but can improve carcasse weight of broiler.
\end{abstract}

Keywords : Broiler, carcasse, and cuttlefish bone flour.

\section{PENDAHULUAN}

Ayam broiler (ayam Pedaging) adalah istilah untuk menyebutkan strain ayam hasil budidaya teknologi yang memiliki karakteristik ekonomis dengan ciri khas yaitu pertumbuhan yang cepat, konversi pakan yang baik dan dapat dipotong pada usia yang relatif muda sehingga sirkulasi pemeliharaannya lebih cepat dan efisien serta menghasilkan daging yang berkualitas baik. Broiler adalah galur ayam hasil rekayasa teknologi yang memiliki karakteristik ekonomis dengan ciri khas pertumbuhan cepat sebagai penghasil daging, masa panen pendek dan menghasilkan daging berserat lunak, timbunan daging baik, dada lebih besar dan kulit licin. Atmomarsono (2004) menjelaskan bahwa ayam broiler terdiri dari sekelompok ayam hasil perkawinan antar 
jenis berbeda dari persilangan bertingkat (sampai 40 tingkat) dengan tujuan memperoleh produk daging dengan waktu singkat dan kondisi lain yang mendukung. Menurut Suprijatna et al. (2005) Ayam broiler adalah ayam yang mempunyai sifat tenang, bentuk tubuh besar, pertumbuhan cepat, bulu merapat ke tubuh, kulit putih dan produksi telur rendah. Selanjutnya dijelaskan bahwa ayam broiler yang berumur 6 minggu sudah sama besarnya dengan ayam kampung dewasa yang dipelihara selama 8 bulan. Keunggulan ayam broiler tersebut didukung oleh sifat genetik dan keadaan lingkungan yang meliputi makanan, temperatur lingkungan dan pemeliharaan. Pada umumnya di Indonasia ayam broiler sudah dipasarkan pada umur $5-6$ minggu dengan berat $1,3-1,6 \mathrm{~kg}$ walaupun laju pertumbuhannya belum maksimum, karena ayam broiler yang sudah berat sulit dijual. Menurut Ayam broiler dapat digolongkan kedalam kelompok unggas penghasil daging artinya dipelihara khusus untuk menghasilkan daging. Umumnya memiliki ciri-ciri sebagai berikut: kerangka tubuh besar, pertumbuhan cepat, pertumbuhan bulu yang cepat, lebih efisien dalam mengubah ransum menjadi daging. Ayam pedaging merupakan jenis ayam yang sangat efisien dalam menggunakan pakan dan produktif dalam menghasilkan daging, dibandingkan dengan unggas lainnya. Keberhasilan budidaya penggemukan ayam pedaging ditentukan oleh 3 faktor, yaitu bibit (genetic), pakan (feed) dan pengelolaan (management). Pakan yang sesuai dengan kuantitas dan kualitasnya akan membuat bibit sanggup menunjukkan performansnya, sehingga pengelolaan pakan harus mampu mencapai tingkat efisiensi yang tinggi agar dicapai pertumbuhan yang cepat.

Pertumbuhan secara umum diartikan sebagai proses perubahan yang meliputi pertambahan berat hidup, pertambahan ukuran, perubahan bentuk, dan komposisi tubuh ternak. Selama proses pertumbuhan terjadi perubahan komponen-komponen tubuh seperti jaringan otot, lemak, tulang dan organ, serta komponen-komponen kimia seperti air, protein dan lemak tubuh (Soeparno, 1994). Judge et al. (1989) menyatakan, bahwa selama pertumbuhan proporsi tulang, daging dan lemak akan mengalami perubahan. Pada awal proses pertumbuhan, proporsi tulang akan mengalami pertambahan lebih cepat dibandingkan dengan daging dan lemak dikarenakan tulang merupakan struktur utama dari tubuh. Kecepatan pertumbuhan relatif berbagai komponen tubuh ternak berbeda satu dengan yang lainnya. Hal ini menghasilkan berbagai komposisi tubuh ternak pada berbagai fase pertumbuhan dan berbagai keadaan lingkungan. Pertumbuhan jaringan tubuh pada ternak daging dibedakan atas 3 tingkatan diantaranya adalah Pertumbuhan tulang dan organ lain, Pertumbuhan jaringan otot, dan Pertambahan bobot karena penimbunan lemak (Rhido, 2011). Perkembangan tulang, daging dan bagian tubuh yang lain akan mempengaruhi komposisi penyusunnya seperti protein, lemak dan karbohidrat. Menurut Lawrie (1995), Pada proses pertumbuhan ada dua hal yang terjadi, yaitu meningkatnya bobot badan sampai mencapai bobot badan dewasa, yang disebut pertumbuhan ("growth") dan terjadinya perubahan konformasi, bentuk badan dan fungsi yang disebut perkembangan ("development"). Pertumbuhan dipengaruhi oleh beberapa faktor, yaitu genetik, nutrisi dan fisiologi lingkungan (Lawrie, 1995), bangsa, bobot lahir, jenis kelamin, umur ternak dan pakan (Tulloh dalam Soeparno, 1994). Pada hampir semua ternak, walau betina lebih cepat mencapai dewasa, namun jantan memiliki laju pertumbuhan yang lebih besar (Lawrie, 1995). Lebih lanjut dinyatakan oleh Lawrie (1995), bahwa ternak yang dipelihara dengan pakan dibawah tingkatan hidup pokok akan memiliki laju pertumbuhan yang rendah. Bahan pakan seringkali kurang dapat dimanfaatkan oleh ternak dikarenakan adanya bahan pakan yang masih kurang atau belum sesuai standard kebutuhan. Salah satu zat pakan yang relatif sedikit dibutuhkan namun memiliki perananan yang cukup penting dalam proses pertumbuhan adalah mineral, diantaranya kalsium (ca) dan phospor (p).Defisiensi minerall dapat menghambat pertumbuhan dalam pemeliharaan ayam pedaging.

Upaya untuk mengatasi permasalahan tersebut maka perlu adanya bahan alternatif yang mudah didapat dan memiliki kandungan mineral yang tinggi. 
Tulang sotong adalah salah satu bahan yang dapat digunakan untuk bahan baku sumber mineral, terutama kalsium dan phospor. Dilihat dari kandungan nutrisinya, tepung tulang sotong banyak mengandung kalsium sehingga manfaat dari tepung tulang tidak lepas dari peranan kalsium, yaitu berperan dalam pembentukan tulang, serta menjaga dari kekeroposan akibat asupan kandungan mineral yang minim. Cangkang sotong biasa digunakan sebagai makanan tambahan bagi karena mengandung kalsium karbonat, sodium klorida, kalsium fosfat dan garam magnesium. Tulang sotong mengandung kalsium karbonat, sodium klorida, kalsium fosfat dan garam magnesium. Nutrisi yang terkandung dalam tepung tulang sotong memiliki kandungan Protein Kasar 5,44\%, Kalsium 36,77\%, dan Pospor 0,34\%. Untuk menjalankan metabolisme dengan normal, tubuh juga memerlukan mineral dalam jumlah tertentu. Jenis mineral bisa dibagi dalam dua kelompok, yaitu : makro mineral, adalah mineral yang dibutuhkan dalam jumlah yang cukup besar di dalam tubuh, misalnya kalsium (Ca), fosfor (P), kalium (K), magnesium (Mg), sulfur 9S), sedangkan mikro mineral, adalah mineral yang dibutuhkan dalam jumlah yang sedikit dalam tubuh, misalnya ferum (Fe), kobal (Co), mangan (Mn) (Widodo, 2006). Pakan ternak yang baik harus mengandung mineral makro dan mikro tersebut dalam komposisi jumlah yang tepat. Beberapa jenis mineral merupakan elemen inorganik yang dibutuhkan oleh ternak untuk proses pertumbuhan dan reproduksi. Jumlahnya memang hanya sedikit, namun komposisi semua jenis mineral yang ada harus tepat. Harus selalu ada dalam kompisisi yang tepat agar keseimbangan tubuh tetap terjaga. Berdasarkan kegunaanya dalam aktifitas hidup ternak, maka mineral dapat dibagi menjadi golongan esensial dan non esensial. Secara umum peranan mineral adalah memelihara kondisi ionik dalam tubuh, memelihara keseimbangan asam basa tubuh dalam hal ini tergantung pada ion $\mathrm{Na}^{+}, \mathrm{K}^{+}$, $\mathrm{Ca}^{2+}, \mathrm{Mg}^{2+}, \mathrm{Cl}^{-}, \mathrm{PO}_{4}{ }^{3-}$ dan $\mathrm{SO}_{4}{ }^{3-}$. Peranan mineral lain adalah memelihara tekanan osmotik cairan tubuh, menjaga kepekaan otot dan syaraf dengan cara berperan dalam tiga lokasi, yaitu syarafnya pada penghantaran stimuli $\left(\mathrm{Na}^{+}\right.$dan $\mathrm{K}^{-}$, pada neuro muskuler $\left(\mathrm{Mg}^{+}\right)$dan pada otot dengan mempengaruhi kontraksinya $\left(\mathrm{Ca}^{2+}\right)$. Selain itu mineral juga berperan mengatur transport zat makanan dalam sel, mengatur permeabilitas membran sel dan kofaktor enzim serta mengatur metabolism(http://www.infoternak.com/fungsimineral-pada-ternak).

Fungsi mineral pada ternak adalah sebagai pembentuk struktur fisiologis, sebagai katalisator sekaligus berfungsi sebagai regulator. Mineral merupakan bagian dari tubuh dan memegang peranan penting dalam pemeliharaan fungsi tubuh, baik pada tingkat sel, jaringan, organ maupun fungsi tubuh secara keseluruhan. Di samping itu mineral berperan dalam berbagai tahap metabolisme, terutama sebagai kofaktor dalam aktivitas enzim-enzim. Keseimbangan ion-ion mineral di dalam cairan tubuh diperlukan untuk pengaturan pekerjaan enzim-enzim, pemeliharaan keseimbangan asam-basa, membantu transfer ikatan-ikatan penting melalui membran sel dan pemeliharaan kepekaan otot dan saraf terhadap rangsangan (Almatsier, 2001). Semua jaringan tubuh ternak mengandung zat mineral dalam jumlah dan proporsi yang sangat bervariasi. Mineral memiliki peranan penting bagi tubuh manusia, baik untuk memelihara fungsi tubuh maupun digunakan dalam berbagai tahap metabolism tubuh. Beberapa mineral berfungsi dalam mengatur proses fisiologi (pengatur tekanan osmotik, transport oksigen, kontraksi otot, dan kepekaan syaraf terhadap rangsangan), elemen essensial bagi enzim serta diperlukan dalam proses pengaturan dan pertumbuhan jaringan dan tulang. Kekurangan mineral tertentu dapat menyebabkan berbagai gangguan fungsi tubuh, seperti terhambatnya pertumbuhan, anemia, dan osteoporosis.

\section{BAHAN DAN METODE}

Pada penelitian ini menggunakan anak ayam pedaging umur 1 hari (Day Old Chick; DOC) sebanyak 60 ekor, dan pakan basal yang diberikan berupa konsentrat ayam pedaging produkst PT. Charoen Phokpand serta air minum diberikan secara adlibitum. Feed supplemen yang ditambahankan dalam pakan basal berupa tepung tulang sotong. 
Desain yang digunakan dalam penelitian ini adalah Rancangan Acak Lengkap (RAL) dengan pertimbangan karakteristik obyek penelitian bersifat homogen, ditinjau dari aspek ternak, jenis kandang dan kondisi geografis tempat penelitian. DOC sebanyak 60 ekor dibagi secara acak dengan jumlah sama ke dalam 4 kelompok perlakuan, dan setiap kelompok perlakuan terdiri dari 3 sub kelompok ulangan dengan jumlah ayam masing-masing sebanyak 5 ekor. Kelompok perlakuan tersebut, yaitu :

1. Kelompok perlakuan kontrol (T-0): Kelompok ayam yang diberi pakan basal konsentrat tanpa penambahan " Tepung Tulang Sotong".

2. Kelompok perlakuan 1 (T-1) : Kelompok ayam yang diberi pakan basal konsentrat dengan penambahan " Tepung Tulang Sotong" sebanyak $1 \%$ dari pakan basal.

3. Kelompok Perlakuan 2 (T-2) : Kelompok ayam yang diberi pakan basal konsentrat dengan penambahan " Tepung Tulang Sotong" sebanyak $1,5 \%$ dari pakan basal.

4. Kelompok perlakuan 3 (T-3) : Kelompok ayam yang diberi pakan basal konsentrat dengan penambahan " Tepung Tulang Sotong” sebanyak 2\% dari pakan basal.

yaitu :

Variabel Penelitian yang diamati,

a. Variable control (T-0) adalah pemberian pakan basal yang berupa konsentrat tanpa adanya penambahan Tepung Tulang Sotong, sebagaimana yang biasa dilakukan oleh peternak pada umumnya.

b. Variable independent adalah penambahan pakan basal yang berupa konsentrat dengan Tepung Tulang Sotong dalam level yang berbeda, yaitu $1 \%, 1,5 \%$ dan $2 \%$ dari pakan basal.

c. Variable dependent adalah Performans Pertumbuhan, yang meliputi Pertambahan Bobot Badan Harian (Average Daily Gain), pertambahan ukuran dan bobot tulang kaki (shank), dan berat karkas.

\section{HASIL DAN PEMBAHASAN}

\section{Konsumsi Pakan}

Rata-rata konsumsi pakan yang dihabiskan oleh ayam broiler umur 1-28 hari pada saat penelitian ditunjukkan pada tabel 7. Rata-rata konsumsi pakan dari keempat perlakuan masing-masing T0, T1, T2 dan T3 adalah 54,59 gram/ekor/hari, 55,71 gram/ekor/hari, 58,77 gram/ekor/hari dan 58,55 gram/ekor/hari. Berdasarkan hasil analisis statistik (lampiran 4), menunjukkan bahwa pemberian tepung tulang sotong berbeda tidak nyata terhadap konsumsi pakan $(P>0,05)$. Hal ini berarti bahwa penambahan tepung tulang sotong hingga level $2 \%$ tidak mempengaruhi konsumsi pakan. Ransum perlakuan (T1, T2, dan T3) masih dalam batas standar kebutuhan setelah diberi penambahan tepung tulang sotong. Kandungan protein kasar dan serat kasar masing-masing perlakuan yaitu protein kasar untuk T0 : 23\%, T1 : 22,40\%, T2 : $21,80 \%$ dan T3 : $21,20 \%$ dan kandungan serat kasar untuk T0 : 4\%, T1 : 3,90\%, T2 : $3,80 \%$ dan T3 : 3,70, sehinggga tidak mempengaruhi konsumsi. Menurut Amrullah (2004) kandungan nutrien ransum ayam pedaging harus dapat mencukupi kebutuhan nutrien dalam jumlah dan persentase yang diinginkan dan nutrien tersebut adalah energi,protein, serat kasar, kalsium (Ca) dan fosfor (P). Menurut Fadilah (2004), kandungan protein dalam ransum untuk ayam broiler umur 1-14 hari adalah $24 \%$ dan untuk umur 14-39 hari adalah $21 \%$. Kebutuhan protein untuk ayam yang sedang bertumbuh relatif lebih tinggi karena untuk memenuhi tiga macam kebutuhan yaitu untuk pertumbuhan jaringan, hidup pokok dan pertumbuhan bulu (Wahju, 1992). Berdasarkan data dari PT. Japfa Comfeed Indonesia (2012), rata - rata standart konsumsi pakan ayam broiler dari strain $\mathrm{MB}$ 202 Platinum yaitu sebesar 67,13 gram/hari. Hasil penelitian menunjukkan bahwa ratarata konsumsi pakan ayam broiler sebesar 56,90 gram/ekor/hari dan lebih rendah dari standar konsumsi pakan ayam broiler.

Pertambahan Bobot Badan Harian (PBBH). Pertumbuhan merupakan proses terjadinya perkembangan tubuh dari seekor ternak. Pada proses pertumbuhan terjadi dua peristiwa, yaitu peristiwa perbanyakan sel (hiperplasia) dan perkembangan (hiperthropia). Indikator terjadinya proses pertumbuhan yaitu pertambahan bobot badan. Data pertambahan bobot badan 
harian $(\mathrm{PBBH})$, yang diperoleh selama penelitian ditampilkan sebagaimana pada Tabel 2. Rata-rata PBBH pada T-0, T-1, T-2 dan T-3 secara berturut-turut adalah 38,8 ; 41,$5 ; 40,6$ dan 38,7 g/ekor/hari. Analisis statistik menunjukkan bahwa $\mathrm{PBBH}$ dari keempat macam perlakuan tersebut adalah berbeda tidak nyata $(P<0,05)$. Hal ini berarti bahwa perlakuan dengan penambahan tepung tulang sotong dalam ransum sampai dengan level 2 persen tidak mempengaruhi kenaikan berat badan. Tidak adanya pengaruh dari penambahan tepung tulang sotong dalam ransum diduga disebabkan karena penambahan tepung tulang sotong dalam ransum tidak mempengaruhi konsumsi pakan yang dihabiskan. Konsumsi pakan T$0, \mathrm{~T}-1, \mathrm{~T}-2$ dan T-3 secara berturut-turut adalah 54,6; 55,7; 58,8 dan 58,6 gram/ekor/hari. Konsumsi pakan tersebut di atas mengakibatkan terjadinya pentumbuhan dan pertambahan berat badan harian yang relatif sama. Hal ini sesuai pendapat Tillman et al. (1991), yang menegaskan bahwa konsumsi pakan memiliki pengaruh yang sangat besar terhadap laju pertumbuhan karena dari pakan tersebut ternak akan memperoleh zat gizi atau nutrien untuk hidup dan pertumbuhan. Menurut Ndegwa et al. (2001), ayam yang mengkonsusmi protein dalam jumlah sama, tingkat pertumbuhannya juga sama. Zhang (1994) menyatakan bahwa ayam broiler memperlihatkan pertambahan bobot badan akhir yang baik dengan ransum yang memiliki kandungan protein dan energi metabolis yang baik pula. Sementara itu Soeparno (1994) dan Parakkasi (1999), menyatakan bahwa pertumbuhan pada ternak yang ditunjukkan dengan $\mathrm{PBBH}$ dipengaruhi oleh faktor pakan (jenis, komposisi kimia dan konsumsi pakan) dan ternak (jenis kelamin, hormon dan genetik).

\section{Karkas}

Data karkas yang diperoleh selama penelitian ditampilkan sebagaimana pada Tabel 6. Secara kuantitatif berat karkas tersebut cenderung meningkat dengan meningkatnya penambahan Tepung Tulang Sotong yaitu tertinggi dicapai pada perlakuan T-3 (770,67 gram/ekor) yang diikuti oleh T-2 (761,67 gram/ekor) dan T1 (750,67 gram/ekor), sedangkan untuk T-0 sebesar 631,33 gram/ekor. Kecenderungan peningkatan berat karkas ini juga diikuti oleh persentase karkasnya. Hasil analisis statistik terhadap karkas memberikan hasil yang tidak berbeda sangat nyata $(P>0,01)$. Hasil tersebut memberikan arti bahwa penambahan Tepung Tulang Sotong sampai dengan aras $2 \%$ sangat berpengaruh terhadap karkas yang dihasilkan. Pengaruh tersebut di atas diduga disebabkan karena perbedaan kandungan mineral kalsium (ca) dan pospor (p) dalam pakan pada ketiga perlakuan, yaitu T-1, T-2 dan T-3 yang lebih banyak sehingga menjadikan perberbedaan pertumbuhan yang lebih baik, khususnya bagian karkas. Soeparno (1994) yang menyatakan, bahwa laju pertumbuhan dan status nutrisi merupakan faktor yang saling berkaitan dalam mempengaruhi karkas atau komposisi tubuh. Menurut Lawrie (1995), apabila kandungan nutrisi dibawah tingkat kebutuhan hidup pokok, maka berbagai jaringan tubuh akan digunakan untuk mensuplai energi dan protein. Menurut Hayse dan Marion (1973) dalam Resnawati (2004) menyatakan bahwa bobot karkas yang dihasilkan dipengaruhi oleh beberapa faktor yaitu umur, jenis kelamin, bobot potong,besar dan konformasi tubuh, perlemakan, kualitas dan kuantitas ransum serta strain yang dipelihara, sementara Tulloh dalam Soeparno (1994), yang menyatakan bahwa salah satu faktor yang dapat mempengaruhi karkas adalah bobot badan ternak itu sendiri.

\section{KESIMPULAN}

Hasil penelitian dapat memberikan kesimpulan bahwa penambahan tepung tulang sotong sampai aras 2 persen dalam ransum belum dapat meningkatkan performans pertumbuhan yang meliputi Pertambahan Bobot Badan Harian (PBBH), dan pertambahan panjang dan bobot Shank, tetapi dapat meningkatkan bobot karkas ayam pedaging. Hasil penelitian ini menunjukkan bahwa penambahan tepung tulang sotong dalam ransum sampai level 2 persen dapat meningkatkan produktivitas ayam pedaging. 


\section{DAFTAR PUSTAKA}

Amrulah, Ibnu Katsir. 2004. Nutrien Ayam Broiler. Lembaga Satu Gunung Budi. Bogor.

Almatsier S. 2001. Prinsip Dasar IImu Gizi. Jakarta: Gramedia Pustaka Utama.

Atmomarsono, U. 2004. Upaya Menghasilkan Daging Broiler Aman dan Sehat. Pidato Pengukuhan, diucapkan pada Upacara Peresmian Penerimaan Jabatan Guru Besar dalam IImu Ternak Unggas pada Fakultas Peternakan Universitas Diponegoro, Semarang 6 Oktober 2004.

Bihan EL, Zatylny C, Perrin A, Koueta N. 2006. Post Mortem Change in Viscera of Cuttlefish (Sepia officinalis L.) During Storage at Two Different Temperatures. Journal Food Chemistry 98(1):39-51.

Fadilah, R. 2004. Ayam Broiler Komersial. Agromedia Pustaka. Jakarta.

http://www.infoternak.com/fungsi-mineralpada-ternak.

Judge, M.D., E.D. Aberle, J.C. Forrest, H.B. Hedrick dan R.A. Merkel. 1989. Principles of Meat Science. Kendall/Hunt Publishing Company. Dubuque. lowa.

Lawrie, R.A. 1995. Meat Science. Low Temperature Research Station. Nottingham University. Cambridge.

Ndegwa, J.M., Mead, R., Norrish, P., Kimani, CW. and Wachira, A.M. 2001. The growth performance of indegenous chickens fed diets containing different level of protein during rearing. Trop. An. Health And Prod. 33: 441-448.

Resnawati, H.2004.Bobot potongan karkas dan lemak abdomen ayam ras pedaging yang diberi ransum mengandung tepung cacing tanah (Lumbricus rubellus). Balai Penelitian Ternak. Bogor.

Rhido, M., 2011. Pertumbuhan dan Perkembangan Ternak. http://emridho.blogspot.com.

Soeparno. 1994. Ilmu dan Teknologi Daging. Gadjah Mada University Press. Yogyakarta.

Suprijatna, E., U. Atmomarsono dan R. Kartasudjana. 2005. IImu Dasar Ternak Unggas. Penebar Swadaya, Jakarta.

Tillman, A. D. S. Reksohadiprojo, S. Prawirokusumo, dan S. Lebdosekejo. 1991. Ilmu Makanan Ternak Dasar. Gadjah Mada University Press, Yogyakarta.

Wahyu, J., 1988. Beternak Ayam Pedaging. PT. Gramedia. Jakarta.

Wahju, J. 1992. IImu Nutrien Unggas. Cetakan III. Gadjah Mada University Press. Yogyakarta.

Widodo, W., 2006. "Pengantar IImu Nutrisi Ternak". Fakultas Peternakanperikanan Universitas Muhammadiyah Malang (UMM).

Zhang. X, Roland, D. A. and S. K. Roat. 1999. Effect of naturphos phytase supllementation to feed on performance and ileal digestibility of protein and amino acid of broiler. Poultry Sci. 78;1567-1572. 
Tabel 1. Komposisi dan kandungan Gizi Pakan Penelitian

\begin{tabular}{|l|c|c|c|c|}
\hline Perlakuan & $T-0$ & $T-1$ & $T-2$ & $T-3$ \\
\hline Nutrisi & & & & \\
\hline 1. PK (\%) & 23,00 & 23,05 & 23,08 & 23,11 \\
2. SK (\%) & 4,00 & - & - & - \\
3. Ca. (\%) & 3,00 & 3,36 & 3,54 & 3,72 \\
4. P. (\%) & 1,50 & 1,50 & 1,51 & 1,51 \\
\hline
\end{tabular}

Tabel 2. Rata-rata konsumsi pakan (gram/ekor/hari)

\begin{tabular}{|r|c|c|c|c|}
\hline Perlakuan & Kontrol & T-1 & T-2 & T-3 \\
\hline 1 & 43,67 & 51,22 & 58,84 & 66,79 \\
2 & 57,17 & 48,31 & 61,11 & 52,01 \\
3 & 62,92 & 67,61 & 56,37 & 56,85 \\
& & & & \\
\hline Jumlah & 163,76 & 167,14 & 176,32 & 175,65 \\
\hline Average & 54,59 & 55,71 & 58,77 & 58,55 \\
\hline
\end{tabular}

Keterangan : Berbeda tidak nyata $(\mathrm{P}<0,05)$

Tabel 3. Data pertambahan bobot badan harian (PBBH).

\begin{tabular}{|c|c|c|c|c|}
\hline \multirow{2}{*}{ Ulangan } & T-0 & T-1 & T-2 & T-3 \\
\cline { 2 - 5 } & \multicolumn{4}{|c|}{ (gram/ekor/hari) } \\
\hline 1 & 37,6 & 40,2 & 40,1 & 39,0 \\
3 & 40,0 & 44,4 & 40,0 & 38,1 \\
Rata-rata & 38,7 & 39,9 & 41,6 & 39,1 \\
\hline
\end{tabular}

Keterangan : Berbeda tidak nyata $(\mathrm{P}<0,05)$

Tabel 4. Data pertambahan panjang shank (cm/ekor)

\begin{tabular}{|r|c|c|c|c|}
\hline Perlakuan & Kontrol & T-1 & T-2 & T-3 \\
\hline 1 & 4,34 & 4,41 & 4,52 & 4,58 \\
2 & 4,48 & 4,82 & 4,46 & 4,45 \\
3 & 4,34 & 4,72 & 4,4 & 4,48 \\
& & & & \\
\hline Jumlah & 13,16 & 13,95 & 13,46 & 13,51 \\
\hline Average & 4,39 & 4,65 & 4,49 & 4,50 \\
\hline
\end{tabular}

Keterangan : Berbeda tidak nyata $(P<0,05)$

Tabel 5. Data berat shank (gram/ekor)

\begin{tabular}{|c|c|c|c|c|}
\hline Perlakuan & \multicolumn{1}{|l|}{ Kontrol } & T-1 & T-2 & T-3 \\
\hline 1 & 20,00 & 24,00 & 20,00 & 20,00 \\
2 & 21,00 & 21,00 & 23,00 & 22,00 \\
3 & 20,00 & 22,00 & 21,00 & 21,00 \\
\hline Jumlah & 61,00 & 67,00 & 64,00 & 63,00 \\
\hline Average & 20,33 & 22,33 & 21,33 & 21,00 \\
\hline
\end{tabular}

Keterangan : Berbeda tidak nyata $(P<0,05)$ 
Widharto \& Marsudi. 2017

Tabel 6. Data berat karkas (gram)

\begin{tabular}{|r|c|c|c|c|}
\hline Perlakuan & Kontrol & T-1 & T-2 & T-3 \\
\hline 1 & 672,0 & 792,0 & 744,0 & 792,0 \\
2 & 588,0 & 708,0 & 780,0 & 750,0 \\
3 & 634,0 & 752,0 & 761,0 & 770,0 \\
\hline Jumlah & 1894 & 2252 & 2285 & 2312 \\
\hline Average & 631,33 & 750,67 & 761,67 & 770,67 \\
\hline
\end{tabular}

Keterangan : Berbeda sangat nyata $(P>0,01)$

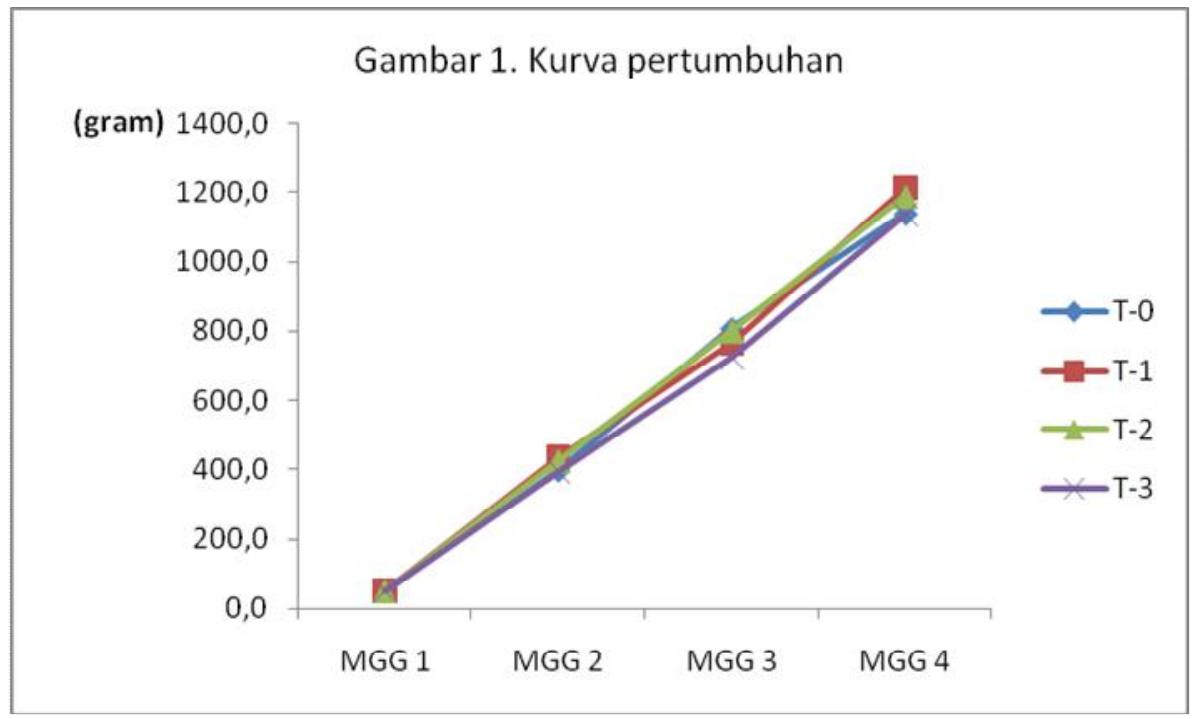

Gambar 1. Grafik Pertumbuhan Ayam

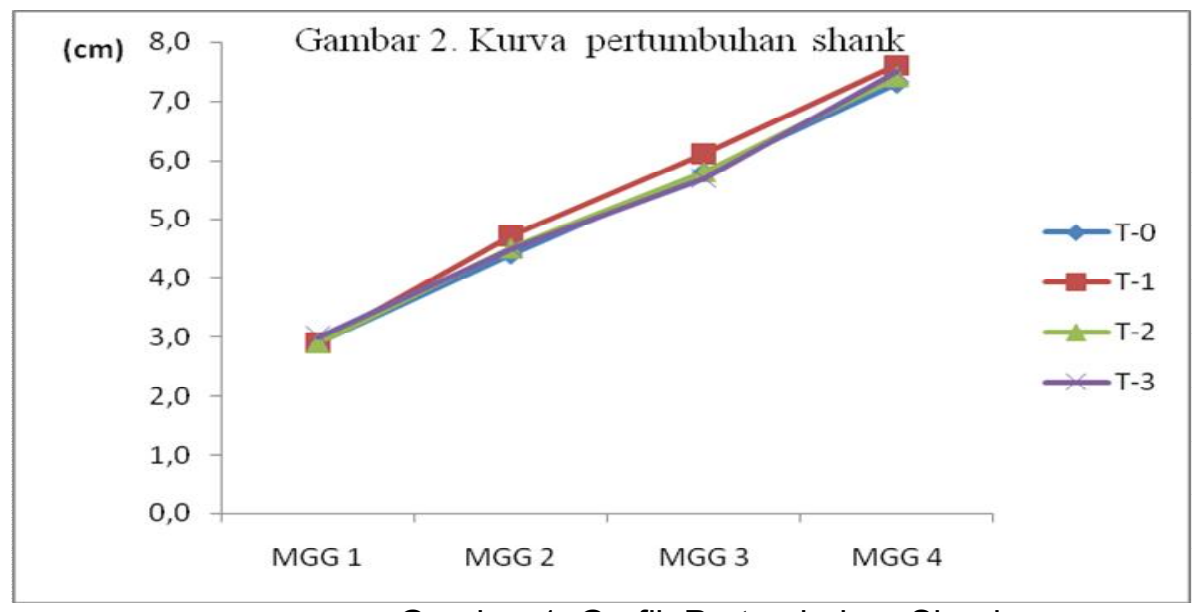

Gambar 1. Grafik Pertumbuhan Shank 